\title{
Economical and social aspects: evaluation of incorporation potential in municipal wastewater reuse procedure in Greece
}

\author{
S. Bakopoulou \& A. Kungolos \\ Department of Planning and Regional Development, \\ University of Thessaly, Volos, Greece
}

\begin{abstract}
It is the objective of this study to evaluate the incorporation potential of economic and social factors in municipal wastewater reuse procedure, aiming at determining whether it is worthwhile for a municipality to construct the necessary advanced treatment systems or not. Advanced wastewater treatment is the additional treatment needed to remove any constituents remaining after conventional secondary treatment and it is considered necessary when there is plan for treated wastewater reuse. Economic and social factors, as well as the necessary environmental factors, could be used as the main parameters, which will serve in the development of an evaluation model. This model could be based in a cost-benefit analysis which, through a correlation procedure, can lead to an optimal solution adoption. This model could be useful for many municipalities in Greece, where wastewater reuse does not consist presently a common method of treated wastewater management.
\end{abstract}

Keywords: wastewater reuse, advanced wastewater treatment, irrigation.

\section{Introduction}

Water scarcity and deterioration in the quality of water resources in many countries have led to the recognition that water shortage and water pollution control should be solved by a careful water resource management that incorporates advanced technologies. Desalination of seawater as well as reclamation and reuse of municipal wastewater are the main strategies that have 
been proposed for investigation and application in many countries all over the world [1]. Treated wastewater could be reused for specific purposes, such as irrigation purposes, industrial uses as well as aquifer recharge purposes. However, the most common reuse application includes agricultural irrigation. On this occasion, wastewater can serve as a source of both water and nutrients, thus reducing fertilization costs. On the other hand, landscape irrigation and other non-potable urban uses are gaining interest in recent years because of modern technology developed specifically for such uses [2].

In Mediterranean area a lot of drainage periods have taken place in recent years, especially in countries like Greece and Portugal. In these countries, the main problem may not be scarcity of water in terms of average per capita, but the high cost of making water available at the right place, at the right time with the required quality [3]. This problem relates mainly to the fact that many municipalities do not show interest in developing advanced treatment systems, which will make secondary effluents suitable for irrigation, because of the economical cost. So, in these countries, more than anywhere else, an integrated approach for water resources management including wastewater reclamation and reuse is required.

Taking in mind the above information, this paper aims at presenting the main problems related to wastewater reuse practices in Greece. These data can assist in developing an evaluation model which could be used as a basis for determining whether it is worthwhile for a municipality to construct advanced treatment systems for making treated effluents suitable for irrigation or not. In Greece, there have been quite some studies regarding issues such as proposals for national guidelines development, but no study about economical evaluation of wastewater reuse procedure.

\section{International current tendencies}

In the Mediterranean basin, Israel has been a pioneer in the development of wastewater reuse practices. It is estimated that by the year 2040, treated sewage effluent will become the main source of water for irrigation in Israel and the Palestinian autonomous regions, supplying 1000 million $\mathrm{m}^{3}(70 \%)$ out of the 1400 million $\mathrm{m}^{3}$, that will be used for irrigation [4]. The Israel "example" was also followed by Cyprus, Jordan, Tunisia, Italy, and France. In these countries, full fledged national regulations set the basic conditions for a safe reuse of wastewater. In rest Mediterranean countries, lack of national regulations has led to the existence of relatively few efforts regarding developing of new projects in wastewater reuse sector. Spain is an exception, since the recent development of regional regulations has had a positive effect in wastewater reuse methods used in this country.

Other countries which have developed national or regional regulations regarding municipal wastewater reuse include USA, Japan and South Africa. USA and more specifically regions like California, Florida and Arizona are pioneers in using extremely modern technology of sewage wastewater recycling. Canada and China have supported in recent years a significant number of 
researches into treatment and reuse of domestic greywater for non-potable uses $[5,6]$.

In 1989 the World Health Organisation set up a research for determining guidelines and regulations for wastewater reuse. These guidelines and regulations were based mainly in findings of epidemiological researches, so the majority of them were referred only to limits like pathogenic microorganisms maximum number. Later, in 1992 the US Food and Agricultural Organism reviewed the previous limits and developed new limits-guidelines regarding chemical, physical and microbiological parameters $[7,8]$.

\section{Present situation in Greece}

In Greece, the distribution and availability of water sources deflect from statistically average values. The most significant problems are noticed in Aegean islands as well as in most of the eastern Greek regions. In these areas rainfalls are relatively few if we compare them with those noticed in western regions of Greece. Nevertheless, reuse of municipal wastewater has not been a common management practice in Greece in reverse with direct disposal in rivers, lakes or sea. Only a few hotel enterprises in coastal areas have used their secondary effluents for landscape irrigation purposes in recent years. As a conclusion, a lot of water quantities are not utilized while a great quantity of potable water is used in non-potable uses like landscape irrigation.

In Greece no guidelines or criteria for wastewater reclamation and reuse have yet been adopted. Secondary effluent quality criteria are used for discharging purposes (No E1b/221/65 Health Arrangement Action) and are independent of the disposal, reclamation and reuse effort. In 2000 the watering and sewage municipal enterprise of Larissa set up a study regarding determining of guidelines for wastewater reuse. The main intention of this study was the initiative estimation of qualitative criteria that should characterize the treated effluents [9]. Later on and more specifically in 2003 a research program regarding wastewater reuse took place under LIFE European Community Initiative in Thessaloniki area. The aims of this research project related to specific guidelines and regulations determination for wastewater reuse, as well as pilot wastewater use for agricultural irrigation and aquifer recharge $[2,10,11]$. The criteria and guidelines allocated in this project were rather specific and detailed compared to older studies.

The above studies set the basis for the legal solution of the problem by enabling the state to incorporate the proposed criteria in national regulations. Furthermore, a lot of studies regarding effects of wastewater irrigation in specific crops have taken place in recent years [12, 13, 14]. However, a crucial point, which should be paid attention to, represents the socio-financial problem regarding wastewater reuse. Many municipalities are not keen on constructing advanced wastewater treatment systems which will make the secondary effluent suitable for reclamation purposes. On the other hand, many Greek farmers are also negative in using such a water source. In an effort to solve these problems, we propose the development of an evaluation model which should incorporate 
the relative financial, social and environmental aspects regarding wastewater reuse and intend at determining if it is worthwhile for a municipality to construct advanced treatment systems or not.

\section{Description of the evaluation model structure}

The evaluation of advanced treatment systems viability could be done by running a model which will incorporate the relative economic, social and environmental aspects regarding wastewater reuse. The economic aspects can be expressed in financial terms directly, while the social and environmental aspects could be expressed in financial terms indirectly using specific techniques. The above model could depend on a cost-benefit analysis which leads to the optimal solution selection.

A cost-benefit analysis (CBA) estimates and totals up the equivalent money value of the benefits and costs of projects so as to determine whether they are worthwhile. In order to reach a conclusion, all aspects of the project, positive and negative, must be expressed in terms of a common unit. The most convenient common unit is money. This means that all benefits and costs of a project should be measured in terms of their equivalent money value. Furthermore, all benefits and costs should be expressed in terms of money value of a particular time. This is due to the differences in the money value at different times because of inflation.

Expression of environmental aspects in financial terms could be done by using specific techniques described in scientific literature like revealed preference techniques and stated preference techniques $[15,16]$. In general, the financial rating of environmental aspects is based on public preference for a specific environmental quality level.

Social aspects could be evaluated by using appropriate questionnaires which will be allocated in farmers of the target area. This method aims at finding out whether the farmers of a specific region are eager to use treated wastewater for irrigation purposes or not. Another important parameter which will be of great importance is the money value that the farmers wish to pay. These data could be used as a benefit in our analysis. On the other hand, if the farmers do not present any intention to buy such a water resource, then we will have a cost in our analysis. All the essential information regarding costs or benefits will arise after the questionnaires have been statistically analysed. During this procedure, all the farmers will be well-informed for the real advantages and disadvantages of using wastewater as a water resource.

Another important benefit in our analysis relates to landscape irrigation and other non - potable urban uses. The use of potable water for irrigation of such landscapes (parks, streets, cemeteries) is a common practice in Greece. If these landscapes were irrigated by treated wastewater, then the potable water would be used in other beneficial uses. The example of Larissa municipality is representative of such an occasion. Larissa is a city located in the central-eastern part of Greece. Its population in 2001 reached close to 130000 inhabitants. Landscapes such as parks and squares cover a great surface of Larissa 
municipality area. Larissa wastewater treatment plant receives wastewater reaching up to $20000 \mathrm{~m}^{3}$ per day and $7200000 \mathrm{~m}^{3}$ per year. Larissa municipal enterprise of watering consumes every year about $500000 \mathrm{~m}^{3}$ for landscape irrigation. If this quantity were derived from recycled wastewater, then the $500000 \mathrm{~m}^{3}$ of potable water would be used in other uses such as drinking. The benefits arising from such a case are significant.

The main structure of our evaluation model is being described in Figure 1.

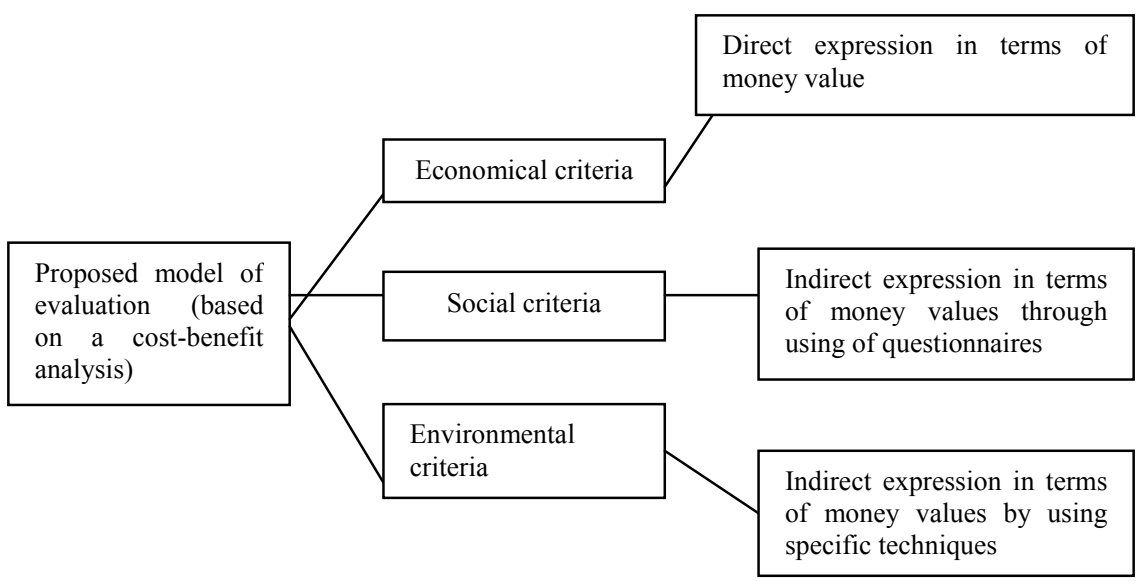

Figure 1: $\quad$ Main structure of proposed evaluation model.

\section{Conclusions}

In this study, the current situation regarding reuse of municipal wastewater for irrigation purposes in Greece was examined. Our main conclusion relates to the fact that there has been an increasing interest in the above sector of waste management in recent years. Projects that are being carried out in this sector can contribute positively in the general strategy of sustainable management of water resources and protection of natural resources from essential pollution. By evaluating economical and social aspects in relation with the necessary environmental ones, one can solve significant problems that have been raised during last years and were well described above.

In conclusion we could say that informing and educating local authorities, workers in wastewater treatment plants and farmers for the real use of wastewater recycling is necessary. The media should also contribute in this effort by informing the local society for how important such water management could be for the protection of natural resources and the environment. 


\section{References}

[1] Brenner A., Shandalov S., Messalem R., Yakirevich A., Oron G., Rebhun M., (2000) "Wastewater reclamation for agricultural reuse in Israel: Trends and experimental results", Water Air Soil Poll., 123: 167-182.

[2] Andreadakis A., Gavalaki E., Mamais D., Noutsopoulos K., Tzimas A., (2003) "Proposal for national guidelines development regarding municipal wastewater reuse in Greece", in proceedings of the conference Reclamation and Reuse of Wastewater, Thessaloniki, 19-75. (in Greek)

[3] Angelakis A.N., Marecos do Monte M.H.F., Bontoux L., Asano T., (1999) "The status of wastewater reuse practice in the Mediterranean basin: Need for guidelines", Water Research, 33 (10):2201-2217.

[4] Haruvy N., Offer R., Hadas A., Ravina I., (1999) "Wastewater irrigation Economic concerns regarding beneficiary and hazardous effects of nutrients", Water Resources Management, 13: 303-314.

[5] Exall K., (2004) "A review of water reuse and recycling, with reference to Canadian practice and potential: Applications", Water Qual. Res. J., 39(1): 13-28.

[6] Chu J., Chen J., Wang C., Fu P., (2004) "Wastewater reuse potential analysis: implications for China's water resources management", Water Research, 38: 2746-2756.

[7] WHO (1989) Health guidelines for the use of wastewater in agriculture and aquaculture, Report of a WHO Scientific Group, WHO technical report series 778 , Geneva.

[8] FAO (1992) Wastewater treatment and use in agriculture, M.B. Pescod, Irrigation and Drainage Paper 47, Rome.

[9] Angelakis A., Tsagarakis K., Kotselidou O., Vardakou E. (2000) A need for national guidelines development regarding reclamation and reuse of municipal wastewater in Greece: Preliminary estimation, Union of Greek Municipal Watering and Sewage Enterprises, Larissa. (in Greek)

[10] Tsiridis V., Petala M., Kungolos A., Samaras P., Sakellaropoulos G.P. (2003) "Reclamation of municipal wastewater using advanced treatment technology", in proceedings of the conference Reclamation and Reuse of Wastewater, Thessaloniki, 77-99. (in Greek)

[11] Georgiadou M., Kakani M., Loubari E., Meladiotis I., Baliaka B., Moutsopoulos K., Naskos N., (2003) "Monitoring and recharge of aquifer with treated wastewater", in proceedings of the conference Reclamation and Reuse of Wastewater, Thessaloniki, 101-116. (in Greek)

[12] Vakalis P. and Tsantilas Ch. (2002) "A study regarding effects of irrigation with treated wastewater in cotton and corn cultivations", Agricultural Research, 25(1): 13-20. (in Greek)

[13] Tsantilas Ch. and Samaras V. (1996) "Use of treated wastewater coming from Larissa treatment plant for agricultural irrigation and fertilization", in proceedings of $2^{\text {nd }}$ national conference Land Reclamation Works, Water Resources Management, and Agricultural Engineering, Larissa, 549-557. (in Greek) 
[14] Paranychianakis N.V., Chartzoulakis K.S., Aggelides S. Amgelakis A.N., (2002) "Grapevine growth and nutrition as affected by irrigation with recycled water", in proceedings of regional symposium on Water Recycling in Mediterranean Region, Iraklio, Greece, 457-464.

[15] Bithas K. (2003) An economic consideration of environmental protection procedure, Tipothito Publications, Athens. (in Greek)

[16] Fletcher J., Adamowicz W., Graham T., (1990) "The travel cost model of recreation demand", Leisure Sciences, 12: 119-147. 